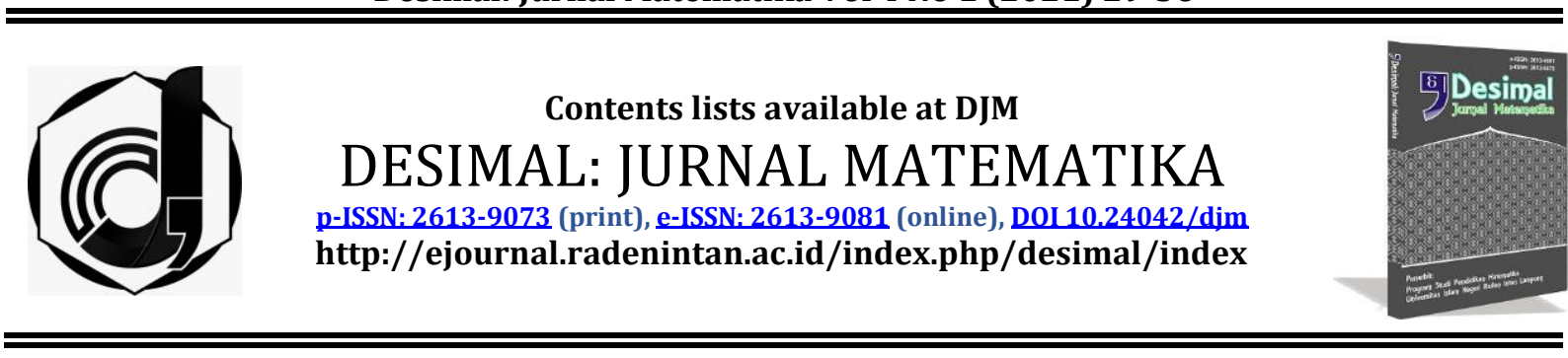

\title{
The practicality of the 7e learning cycle LKS model with a scientific approach to facilitate students' mathematical connection abilities
}

\author{
Azizah*, Zuhri D, Maimunah \\ Universitas Riau, Indonesia
}

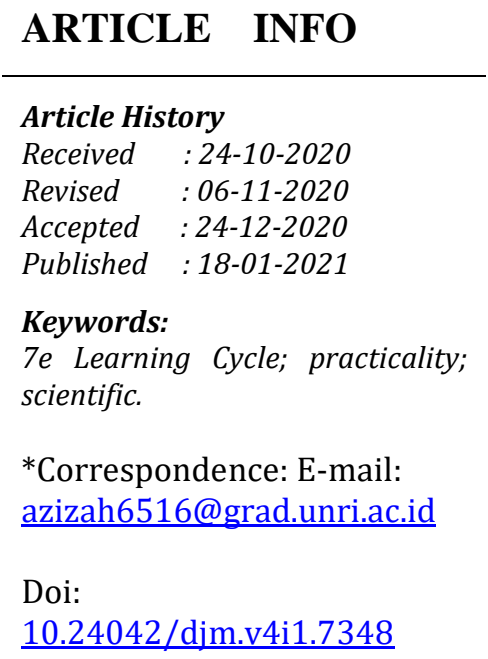

\begin{abstract}
This study aims to describe the practicality of the 7e learning cycle LKS model with a scientific approach to facilitate students' mathematical connection abilities. The research and development with the ADDIE model consist of the stages of analysis, design, development, implementation and evaluation. The practicality test of the LKS was carried out for small group trials of 9 students at the implementation stage. The method used is descriptive statistics to get the average value and percentage. Learning tools are said to be practical if their minimum level of practicality is practical. Based on the analysis of the results of student response questionnaires, the average percentage of student response questionnaires was $91.59 \%$ and was categorized as very practical. This means that this LKS is easy to use and useful for students.

http://ejournal.radenintan.ac.id/index.php/desimal/index
\end{abstract}

\section{INTRODUCTION}

The Organization for Economic Cooperation and Development (OECD) held a Programme for International Student Assessment (PISA) to monitor the learning outcome of students from each participating country covering 3 literacies, one of which is mathematical literacy. Mathematics literacy that is rated at PISA, includes the problems that may be found every day where students solve it by using mathematics (Sujudi et al., 2020). The result of Indonesian students' ability in mathematical literacy of PISA survey in 2018 is ranked 7 th from the bottom with a score of 379. This result shows the ability of Indonesian students are still in the low level compared to the score of 489 which is the OECD average.

Based on the Indonesian students' results at PISA in 2018, it shows that their mathematical ability to solve math problems is still not optimal. Mathematics problem solving is a students' activity that build mathematical connection skills. This happens because in solving a math problem, students must have the ability to find related concepts or theorems that used to determine the solution of a problem (Romli, 2016). 
One of the objectives of mathematics learning according to the 2013 curriculum is to understand mathematical concepts, explain the relation between concepts and applying concepts or algorithms in a flexible, accurate, efficient, and precise way in problem solving (Permendikbud, 2014).

Based on the description above, every student needs mathematical connection skills in solving math problems. This is due to the ability of mathematical connection, students are able to find the relation between mathematical topics, the relation between mathematics and other fields of science, and the relation of mathematics in everyday life so that they can find solutions to mathematical problems (Kusmanto \& Marliyana, 2014).

In fact, students are still classified as having a low level of mathematical connection ability. This can be concluded from the result of a research conducted by Ruspiani (2000, as cited in Muchlis et al., 2018), namely the level of students' mathematical connection ability in high school is low based on the average acquisition of mathematical connection ability scores which consist of finding the relation between mathematical topics around $22.2 \%$; finding the relation between mathematics and other fields of science around 44.9\%; finding the relation of mathematics in everyday life around 7.3\%. Likewise Sholekah et al. (2017), in their research, it shows that students will face difficulty to understand the concepts, to use principles, and to solve verbal problems if the level of mathematical connection ability is low.

The researcher interviewed the mathematics teacher of MAN 1 Indragiri Hilir. Then, it was found that the mathematics problems that were solved by the students were the questions taken from the publisher's reference book. The teachers focus on learning outcomes and do not develop the questions that are oriented towards mathematical connection abilities.

The researchers conducted a preliminary study on the students of MAN 1 Indragiri Hilir to measure the students' ability to find the relation between mathematical topics which are the ability of mathematical connection indicator as follows:

Look at Figure 1 below.

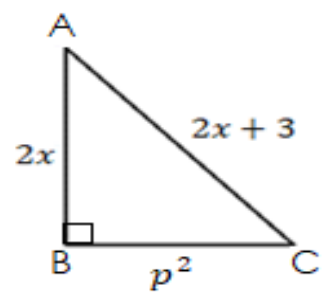

Figure 1. $\triangle A B C$

Calculate the area of $\triangle A B C$ if $p^{2}=21$ (Rosliana, 2019).

Based on the analysis results of the problem solving carried out by students, there are only 5-8 students out of 36 students in one class who can solve the problems given correctly. Students who cannot find the solutions to the problem, it is because students immediately propose the steps to solve the problems without finding the relation of known and asked with facts, concepts, mathematical principles on the problem; and there are also students who can find the relation of known and asked with facts, concepts, mathematical principles on problems, but still make mistakes in determining the results of arithmetic operations.

The analysis results of the problem solving carried out by students are not good enough because students have not been able to find the relation between mathematics topics. The results of research Meylinda \& Surya (2017) shows that students' mathematical connection ability are not good because students have problems in finding the relation between concepts that have been learned and 
cannot recognize also use mathematical ideas to solve mathematical problems.

It needs an effort to improve the learning process so that students' mathematical connection skills can be improved. The learning process must be in accordance and in line with the curriculum. The scientific approach is applied to the implementation of the current 2013 curriculum learning process which consists of scientific activities in the form of observing, questioning, trying, reasoning, and communicating.

The implementation of the scientific approach makes student-oriented learning process, because students are encouraged to seek knowledge from various sources. This is in line with the $7 \mathrm{e}$ learning cycle model where students gain new understanding with the owned understanding capital (Rosliana, 2019).

According to Laelasari et al. (2014), a learning model that is centered on learning participants is the learning cycle. The learning cycle model is integrated activities that makes student-centered learning process, where investigations and discoveries are carried out by students to seek and understand new materials by relating it to the previous experiences that have been obtained (Agustyaningrum, 2011).

Based on the expert's opinion, it is concluded that the learning cycle model is a learning model that has stages of activities carried out by students to construct new understanding materials so that the learning process will be studentcentered.

The learning cycle model initially consisted of 3 stages, namely exploration, concept introduction, and concept application that described by J. Myron Atkin, Robert Karplus, and the Science Curriculum Improvement Study (SCIS) group, at the University of California, Berkeley, United States since 1967. There is a development in the 3 stages of the learning cycle model. In the mid-1980s, BSCS (Biological Science Curriculum Study) developed the learning cycle model into 5E, namely engage, explore, explain, elaborate, and evaluate. Furthermore, Eisenkraft (2003, as cited in Rawa et al., 2016) developed the learning cycle model into 7E, namely elicit, engage, explore, explain, elaborate, extend and evaluate.

The 7e learning cycle model has in line stages with the indicator aspects or mathematical connection abilities. Student activities connect mathematical concepts that they have previously had to find new mathematical concepts and apply them to solve mathematical problems that are at elicit, engage, explore, explain, and elaborate stages. This is in line with the aspect of connection indicators between mathematical topics. Student activities apply the concepts they already have to new problems related to mathematics, science other than mathematics, and everyday life that are at the extend and evaluate stages. This is in line with the aspect of connection indicators between sciences other than mathematics and everyday life.

Based on the description above, the researchers hope that learning with the $7 \mathrm{e}$ learning cycle model and the scientific approach has the opportunity as a more practical learning towards students' mathematical connection abilities. The purpose of this study is to describe the practicality of the 7e Learning Cycle Model Student Worksheet (LKS) with a scientific approach to facilitate the mathematical connection skills of students of MAN 1 Indragiri Hilir.

\section{METHOD}

The type of this research is the development research (research and development) ADDIE model. Here are presented the ADDIE stages and schematic phases of research. 
Desimal, 4 (1), 2021 - 32

Azizah, Zuhri, D., Maimunah

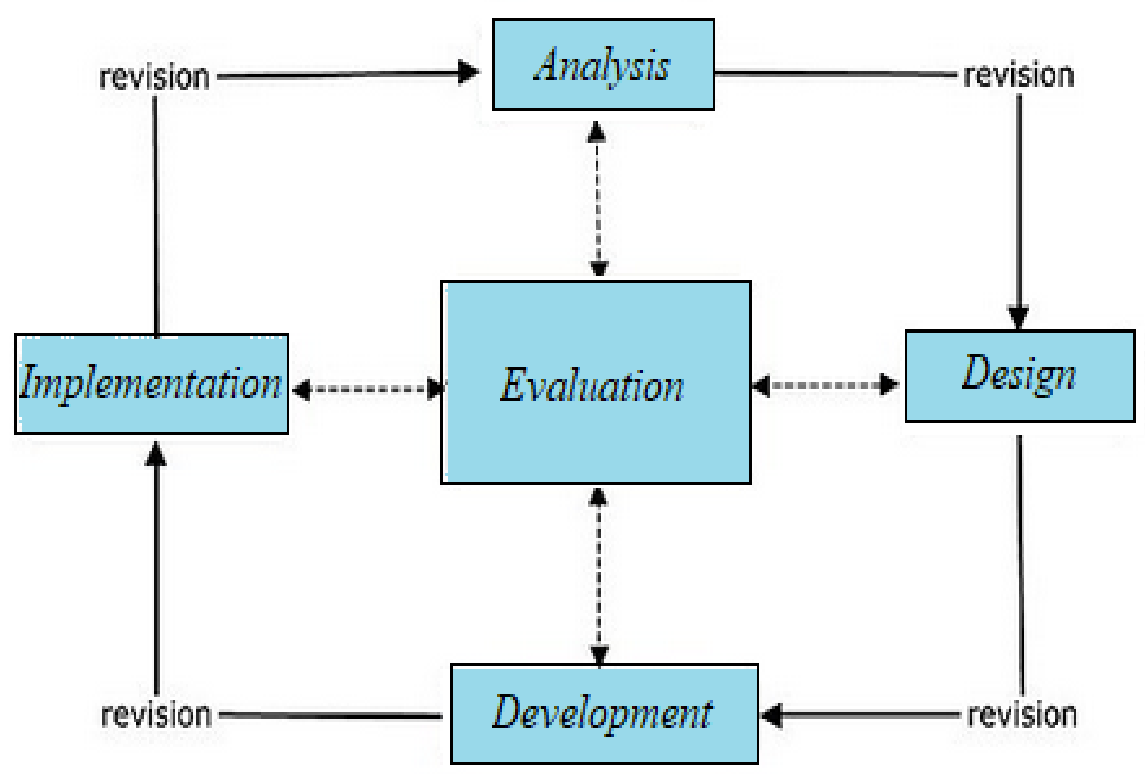

Figure 2. ADDIE Stages

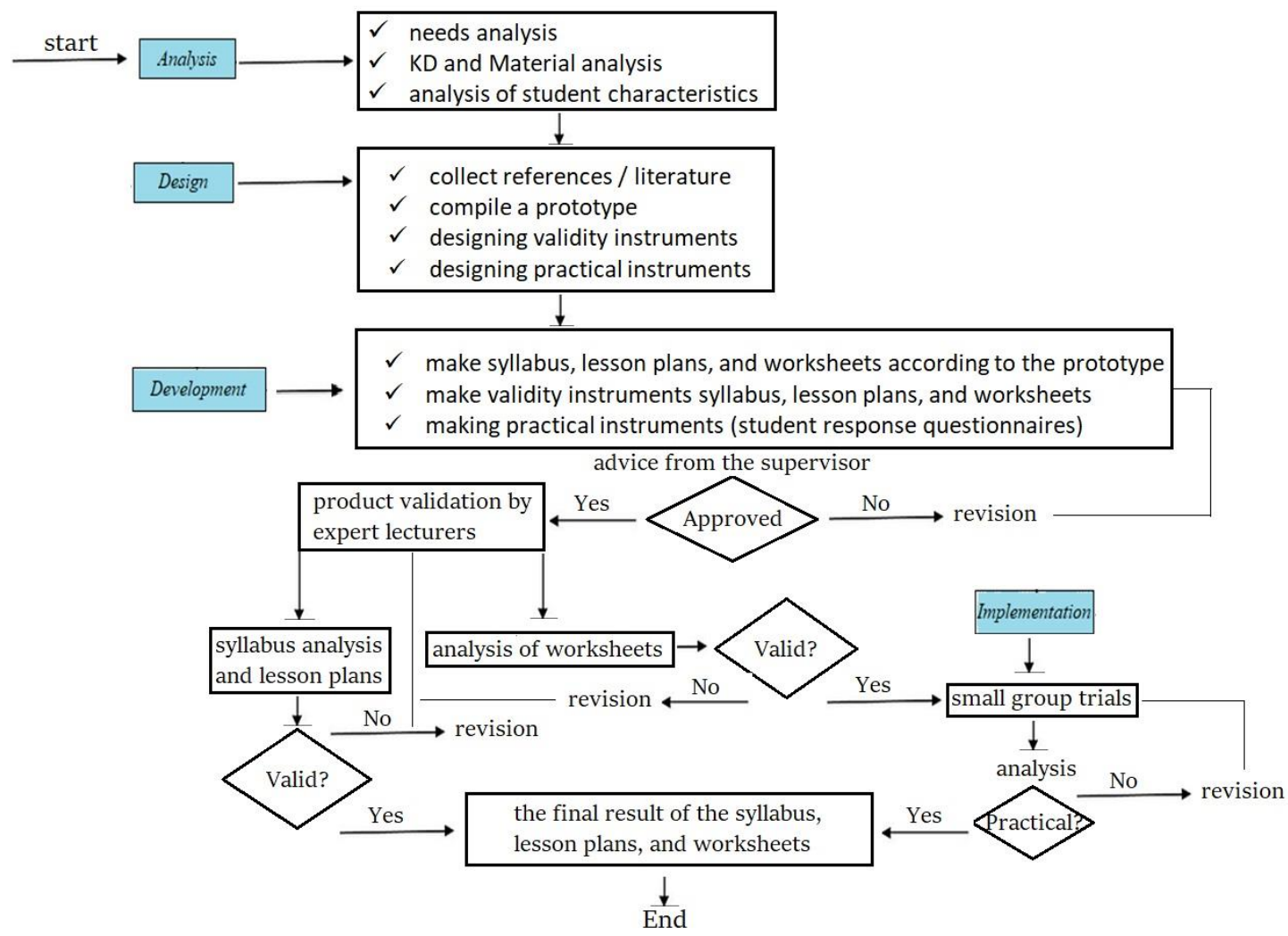

Figure 3. Research Scheme

Research subjects in small group trials were conducted on 9 students of class XI MS MAN 1 Indragiri Hilir. The data collection and analysis techniques are as follows.

(1) Validation Sheet
The obtained data after the validation process is then analyzed by reviewing the results of the assessment and suggestions from the validator. Revision and improvement of students' 
Desimal, 4 (1), 2021 - 33

Azizah, Zuhri, D., Maimunah

LKS are carried out based on the results of the review in order to obtain valid LKS.

The validity of LKS is analyzed by using a formula as follows:

$$
\bar{M}_{V}=\frac{\sum_{i=1}^{n} \bar{V}_{l}}{n}
$$

(Sudjiono, 2011)

Remarks:

$\bar{M}_{V}:$ total average of the validity

$\bar{V}_{i}$ : the average validation of the $i$-th validator

$n \quad$ : the number of validators

The average total of validity results is organized according to the following categories.

Table 1. Validity Category

\begin{tabular}{cc}
\hline Category & Interval \\
Very Valid & $4,2 \leq \bar{M}_{V}<5$ \\
Valid & $3,4 \leq \bar{M}_{V}<4,2$ \\
Less Valid & $1,6 \leq \bar{M}_{V}<3,4$ \\
Not Valid & $0,8 \leq \bar{M}_{V}<1,6$ \\
Very Not Valid & $\bar{M}_{V}<0,8$ \\
\hline & (Sugiyono, 2014)
\end{tabular}

LKS is said to be valid and worthy to be tested if a minimum level of validity obtained is valid.

(2) Student Response Questionnaire

Students fill out a response questionnaire after did the 7e learning cycle model LKS with a scientific approach to facilitate students' mathematical connection skills. The data obtained after the questionnaire filling process were then analyzed by examining the results of students' assessments of using LKS. Revision and improvement of LKS are carried out based on the review results in order to obtain practical LKS.

Practicality learning tools that is developed was analyzed by using a formula as follows:

$$
V_{p}=\frac{T_{s p}}{T_{s h}} \times 100 \%
$$

Remarks:
$V_{p}:$ Respondent score

$T_{s p}$ : The total empirical score of the respondents

$T_{s h}:$ The expected maximum total score

The percentage result of practicality data of LKS is organized in accordance to the categories that are presented as follows:

Table 2. Practicality Category

\begin{tabular}{cc}
\hline Category & Interval \\
Very Practical & $80 \leq P \leq 100$ \\
Practical & $60 \leq P<80$ \\
Less Practical & $40 \leq P<60$ \\
Impractical & $20 \leq P<40$ \\
Very Impractical & $0 \leq P<20$ \\
\hline & (Riduwan, 2013)
\end{tabular}

Learning tools that is developed in the form of LKS are said to be practical if the minimum level of practicality obtained is practical.

\section{RESULTS AND DISCUSSION}

This development research produced a product, namely the 2013 curriculum mathematics learning tools in the form of a syllabus, lesson plans, and student worksheets based on the $7 \mathrm{e}$ learning cycle model to facilitate students' mathematical connection skills in the determinant and inverse matrix material for class XI SMA / MA. This development research aims to produce a valid syllabus, lesson plans, and worksheets that meet the practical requirements by using the ADDIE development research stages. The ADDIE model consists of 5 stages, namely Analysis, Design, Development, Implementation, and Evaluation.

At the stage of Analysis, the development activity that conducted by researchers is the needs analysis to define the basic problem that is faced so that solution is required to the problems; KD analysis and material to formulate GPA based on KD, describe learning objectives, and drafting a concept; and student characteristics analysis. 
In the results of the needs analysis, the basic problem was found in the syllabus that the teacher developed, it did not yet meet the minimum components in accordance with the standard process in (Permendikbud, 2016). The syllabus that the teacher developed only contained identity, KI, KD, learning materials and learning activities. The learning activities column do not yet refer to a learning model, whereas the lesson plan refers to a learning model. Next, the basic problem in the lesson plan developed by teacher was found, that are operational verb that is used in the GPA have not been able to measure the achievement of learning; facts, concepts, principles, and procedures in the learning materials are not quite right; not known clearly the device, tools / materials are used in the current learning activities; and the assessment does not involve students' mathematical connection ability. Subsequently found LKS that used by students are not in accordance with the learning model that is selected in the learning plan because the LKS were not developed by the teacher. Furthermore, in this research, the KD analysis results and materials were formulated by the determined KD. The results of the student characteristics analysis are students seems actively discussing based on the researcher observation and have the heterogeneous academic ability based on the results of the mathematical connection ability test that researchers give to the students.

At the stage of Design, the development activities that conducted by researchers are making initial draft (Prototype) of learning tools such as syllabus, lesson plans and LKS for determinant and inverse matrix materials; make a validation sheet design of the learning tools for the validator; and create a questionnaire response draft of student.

The design of the syllabus, lesson plans, and LKS are adjusted to the stages of the 7e learning cycle model and involves students' mathematical connection skills. The systematics preparation of the syllabus and lesson plans were developed by Permendikbud (2016). The preparation of activities which are on LKS based on the learning model on the lesson plans. Those activities are expected to make students active in the learning activities to find concepts and solve determinant and inverse matrix problems by using the knowledge that has been owned previously and meet the requirements of didactic, construction, and technical. Furthermore, designing a validation sheet of the learning tools and questionnaire response of students based on appraisal aspects that have been assigned.

At the stage of Development, the development activity that conducted by researchers were developing the learning tools such as syllabus, lesson plans and LKS for determinant and inverse matrix material in accordance with the prototype; and product validation and revision. Then, product is consulted to mentors in order to obtain feedback and suggestion for improvements so that the product is ready to be validated. Product validation is done by 2 Mathematics Education lecturers at the Islamic University of Riau and 1 mathematics teacher at SMAN 1 Kateman. In the results of syllabus validation analysis, the syllabus average validation that is given by validator on the rated aspects is 4.24 and considered valid. Validators also gave feedback on some assessment indicators that is a conformity indicator of learning activity using the $7 \mathrm{e}$ learning cycle model; and the conformity indicators of assessment learning results using the curriculum of 2013. Next is the results of learning plan validation, it is obtained an average of learning plan validation that were given by validator on the rated aspects is 4.25 and considered very valid. The validator also gave suggestions on several assessment indicators, namely learning steps, there 
are opinions that must not be written down; the learning steps at the stage 3 is explore; and closing activities. Furthermore, in the analysis results of LKS validation, the average LKS validation is 3.90 and considered valid. Validator also gave suggestions on some assessment indicator, those are LKS should be given a number in sequence on pages cover; stage 1 Elicit, solution column contain Polya stage; and stage 2 Engage, set the system layout for students' activities and provide an enough space for the student to write the answers.

The result of the product validation with a minimum validity is used as the basis to revise the product. Furthermore, the researchers carry out the activity of group testing on the product which has been declared a minimal valid and revised in accordance with the suggestion at the stage of Implementation. The activity of group testing in this research is a small group testing. The products were tested only LKS which was held as much as 4 times, it was on Tuesday, $22^{\text {th }}$ of September 2020 conducted a testing for LKS-1 and LKS-2. On the day of Thursday, $24^{\text {th }}$ of September 2020 conducted a testing for LKS-3 and LKS-4. On the day of Monday, $28^{\text {th }}$ of September 2020 conducted a testing for LKS-5 and LKS-6. On the day of Tuesday, 29th of September 2020 conducted a testing for LKS-7.

The results obtained in a small group testing is the percentage of questionnaire responses against the 7e learning cycle model LKS to facilitate the students' mathematical connection ability on the determinant and inverse matrix material of class XI SMA / MA amounting to $91.59 \%$ and categorized as very practical.

Based on the validation results and the students' response questionnaire results toward the syllabus, lesson plans, and LKS based on the 7e learning cycle model with a scientific approach to facilitate students' mathematical connection abilities in the determinant and inverse matrix material for class $\mathrm{XI}$ SMA / MA, it can be concluded that the syllabus, lesson plans, and LKS based on the $7 \mathrm{e}$ learning cycle model with a scientific approach to facilitate the students' mathematical connection abilities to the determinant and inverse matrix material for class XI SMA / MA is valid and meets the practical requirements. In line with the results of the research that shows learning tools based on the 7e learning cycle model on trigonometric material for class $\mathrm{X}$ high school students are declared valid, practical and effective (Rawa et al., 2016), and LKPD products based on the $7 \mathrm{e}$ learning cycle model for class XI SMA which is valid and practical (Anggraini et al., 2016).

\section{CONCLUSIONS AND SUGGESTIONS}

The 7e learning cycle model LKS to approach scientific to facilitate the students' mathematical connection skills already meet the category of practicality.

The researchers limit the developed learning tools to be validated, namely syllabus, lesson plans, and worksheets (LKS). The researchers made a power point visual media, but only as a support for learning activities. The researchers suggest the readers who are interested in developing this research by the learning tools in the form of media is validated and the researchers suggest the teacher to familiarize students by giving questions that involve students' mathematical connection abilities.

\section{REFERENCES}

Agustyaningrum, N. (2011). Implementasi model pembelajaran learning cycle 5E untuk meningkatkan kemampuan komunikasi matematis siswa kelas IX B SMP negeri 2 sleman. Seminar Nasional Matematika Dan Pendidikan Matematika.

Anggraini, W., Anwar, Y., \& Madang, K. (2016). Pengembangan lembar kerja peserta didik (LKPD) berbasis 
Desimal, 4 (1), 2021 - 36

Azizah, Zuhri, D., Maimunah

learning cycle 7E materi sistem sirkulasi pada manusia untuk kelas XI SMA. Jurnal Pembelajaran Biologi: Kajian Biologi Dan Pembelajarannya.

Kusmanto, H., \& Marliyana, I. (2014). Pengaruh pemahaman matematika terhadap kemampuan koneksi matematika siswa kelas VII semester genap SMP negeri 2 kasokandel kabupaten majalengka. Eduma: Mathematics Education Learning and Teaching. https://doi.org/10.24235/eduma.v3 i 2.56

Laelasari, L., Subroto, T., \& Karimah, N. I. (2014). Penerapan model pembelajaran learning cycle 7E dalam kemampuan representasi matematis mahasiswa. Euclid. https://doi.org/10.33603/e.v1i2.34 7

Meylinda, D., \& Surya, E. (2017). Kemampuan koneksi dalam pembelajaran matematika di sekolah. Jurnal Pendidikan Matematika.

Muchlis, A., Komara, E. S., Kartiwi, W., Nurhayati, N., Hendriana, H., \& Hidayat, W. (2018). Meningkatkan koneksi matematis siswa SMP melalui pendekatan open-ended dengan setting kooperatif tipe NHT. KALAMATIKA Jurnal Pendidikan Matematika.

https://doi.org/10.22236/kalamatik a.vol3no1.2018pp81-92

Permendikbud. (2014). Peraturan mentri pendidikan dan kebudayaan RI Nomor 58 tahun 2014 tentang kurikulum 2013 SMP.

Permendikbud. (2016). Peraturan mentri pendidikan dan kebudayaan RI nomor 22 tahun 2016 tentang standar proses pendidikan dasar dan menengah.

Rawa, N., Sutawidjaja, A., \& Sudirman, S. (2016). Pengembangan perangkat pembelajaran berbasis model learning cycle 7E pada materi trigonometri untuk meningkatkan kemampuan koneksi matematis siswa. Jurnal Pendidikan - Teori, Penelitian, Dan Pengembangan.

Riduwan. (2013). Belajar mudah penelitian untuk guru karyawan dan peneliti pemula. In Belajar Mudah Penelitian Untuk Guru Karyawan dan Peneliti Pemula.

Romli, M. (2016). Profil koneksi matematis siswa perempuan SMA dengan kemampuan matematika tinggi dalam menyelesaikan masalah matematika. MUST: Journal of Mathematics Education, Science and Technology.

https://doi.org/10.30651/must.v1i2 .234

Rosliana, I. (2019). Pengembangan LKPD matematika dengan model learning cycle $7 \mathrm{E}$ berbantuan mind mapping. Jurnal Pengembangan Pembelajaran Matematika (JPPM).

Sholekah, L. M., Anggreini, D., \& Waluyo, A. (2017). Analisis kesulitan siswa dalam menyelesaikan soal matematika ditinjau dari koneksi matematis materi limit fungsi. WACANA AKADEMIKA: Majalah Ilmiah Kependidikan. https://doi.org/10.30738/wa.v1i2.1 413

Sudjiono, A. (2011). Pengantar evaluasi pendidikan. In Pengantar Evaluasi Pendidikan. Raja Grafindo Persada.

Sugiyono. (2014). Metode penelitian pendidikan pendekatan kuantitatif, kualitatif dan R\&D. In METODE PENELITIAN ILMIAH.

Sujudi, M. S., Idris, T., Suryanti, \& Handayani, P. H. (2020). Profil kemampuan literasi sains siswa SMP islam as-shofa kota pekanbaru berdasarkan PISA. 3, 58-69. 